\title{
Investigation of fines migration for a high-pressure, high-temperature carbonate gas reservoir offshore Malaysia
}

\author{
Y. A. Sazali' · W. M. L. Sazali ${ }^{1}$ - J. M. Ibrahim ${ }^{2}$-G. Graham ${ }^{3}$ · S. Gödeke ${ }^{4}(\mathbb{C}$
}

Received: 5 January 2020 / Accepted: 15 May 2020 / Published online: 3 June 2020

(c) The Author(s) 2020

\begin{abstract}
A high $\mathrm{CO}_{2}$ carbonate gas field offshore Sarawak, Malaysia, is scheduled for development. Fines migration has been identified as a potential risk for a sustained and stable production for this field, triggering this investigation. The reservoir investigated (subdivided in S3, S2, S1 formation) has an average 8\% clays, of which over 50\% are migratory illites and $15 \%$ migratory kaolinite. This paper discusses the laboratory findings and factors contributing to fines migration for this reservoir. We conducted core flood tests to determine critical flow rates for the onset of fines migration of high $\mathrm{CO}_{2}$ hydrocarbon gas and $\mathrm{CO}_{2}$-saturated brine within the production gas zone. In addition, we measured total suspended solids during each incremental rate stage and performed scanning electron microscopy-energy-dispersive X-ray (SEM-EDX) analysis on the effluents collected. We also performed mineralogical analysis of formation rocks to determine clay types, amount, and morphology. Core floods performed with $\mathrm{CO}_{2}$-saturated brine on $\mathrm{S} 3$ and $\mathrm{S} 2$ cores showed damage at a critical flow rate of $10 \mathrm{ml} / \mathrm{min}$ with permeability recovery of $65-75 \%$. This shows that $\mathrm{CO}_{2}$-saturated brine tends to mobilize the fines such as illite and kaolinite. Core floods performed with high $\mathrm{CO}_{2}$ hydrocarbon gas showed permeability recovery of $93-96 \%$ at rates up to $10 \mathrm{ml} / \mathrm{min}$. SEM analysis on effluents collected showed presence of silicate and carbonate particles with size of 5-50 $\mu \mathrm{m}$. A combined salt dropout and fines mobilization core flood showed a higher degree of formation damage due to fines mobilization with $74 \%$ permeability recovery compared to baseline permeability compared to core floods with high $\mathrm{CO}_{2}$ hydrocarbon gas. However, the formation damage due to fines mobilization for this experiment was reversible. Overall, the results indicate that a high potential for fines migration in this type of carbonate system exists for $\mathrm{CO}_{2}$-saturated brine flow with significant less potential for dry $\mathrm{CO}_{2}$ flow.
\end{abstract}

Keywords Carbon capture and storage $\cdot$ Malaysia $\cdot$ Core flood $\cdot$ Fines migration $\cdot$ Salt dropout

Electronic supplementary material The online version of this article (https://doi.org/10.1007/s13202-020-00915-3) contains supplementary material, which is available to authorized users.

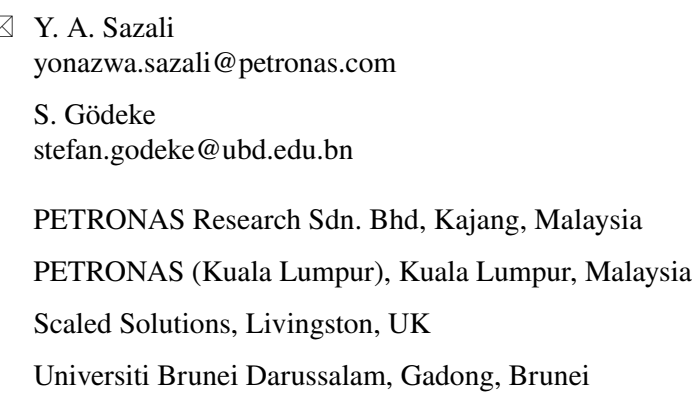

\section{Introduction}

The increase in $\mathrm{CO}_{2}$ as a greenhouse gas in the atmosphere has triggered efforts to reduce greenhouse gas emissions and significant research efforts, one of them being $\mathrm{CO}_{2}$ sequestration, which foresees the injection of $\mathrm{CO}_{2}$ into the subsurface. Malaysia is considering carbon capture and storage (CCS) as a possible way to reduce its greenhouse gas emission footprint. In this respect, it is critical to prove that the (re-) injection of $\mathrm{CO}_{2}$ does not have any adverse impacts (e.g. Kashim et al. 2019). An offshore carbonate reservoir scheduled for development has been identified in which all aspects of CCS are investigated in detail.

It is well known that fines migration can cause significant permeability reduction in subsurface formations associated with oil and gas as well as water production (Civan 2014). This formation damage may require massive stimulation 
treatments in order to alleviate the impact caused (e.g. Ali et al. 2015; Gharbi et. 2014; Goedeke et al. 2012).

The migration of fines can occur in conventional as well as unconventional reservoirs. As fines move through a porous medium, they can be deposited and if the deposition occurs in the pore throats, a severe reduction in permeability may result (Economides et al. 2013). High flow rates and low salinities have been identified as key issues triggering fines migration (e.g. Russel et al. 2018). Usually, in the case of gas-water flow, the fines move with the wetting water phase (e.g. Bennion et al. 2000; Miranda and Underdown 1993). However, fines movement prior to water movement has been observed in a number of gas reservoirs, e.g. due to well perforating jobs (Paveley 2002, Watson 2001). Generally, fines migration may be less prominent in carbonates than in sandstone reservoirs, but there are very few studies which investigate fines migration in carbonate formations. Most studies have investigated fines (such as clay minerals) migration in sandstones (Zhang et al. 2020; Pearce et al. 2019; Sokama-Neuyam et al. 2017; Xie et al. 2017). Carbonates on the other hand can contain clay minerals as well. In particular dissolution of carbonates may enhance the exposure of clay mineral surfaces (Othman et al. 2018). The dissolution of carbonates may occur during $\mathrm{CO}_{2}$ injection or production of $\mathrm{CO}_{2}$-saturated brine. Thus, this study looks into potential fines migration during $\mathrm{CO}_{2}$-saturated brine flow for a carbonate reservoir.

Fine particles, either formed authigenic or detrital and located on the surface of rock grains, are affected by adhesion, drag, lift, electrostatic and gravitational forces. Drag and lifting forces are trying to detach the particle, while Van der Waals and gravitational forces press the particle to the rock grain surface (e.g. Bedrikovetsky et al. 2011). Once mobilized, the fine particles can bridge on the pore throats if its size exceeds the pore size of the matrix (e.g. Oliveira et al. 2014). This bridging can occur when the particles are on the order of one-third to one-seventh the size of the pore throats or larger (e.g. Economides et al. 2013). Fines remain attached to pore surfaces by electrostatic and van der Waals forces. When the repulsive electrostatic forces exceed the attractive van der Waals forces, the fines are released from the pore surfaces (Bennion 1999). At high salt concentrations, $>2 \%$, the van der Waals forces are sufficiently large to keep the fines attached to the pore surfaces. As the salinity is decreased, the repulsive electrostatic forces increase because the negative charge on the surfaces of the pores and fines is no longer shielded by the ions. It has long been realized from core flooding experiments that particle release due to changes in salinity and flow rate can happen almost instantaneously (Miranda and Underdown 1993; Bedrikovetsky et al. 2011). Of particular importance is a decrease in salinity leading to particle mobilization (e.g. Schembre and Kovscek 2005). This decrease in permeability due to decreasing salt concentration has been found to be dependent on the kaolinite content. Permeability impairment due to kaolinite fines has been reported recently (Xie et al. 2017). Clay stabilizing chemicals could be utilized to avoid the risk of formation damage due to clay fines (e.g. Frenier and Ziauddin 2014). However, injection of additional chemicals can also lead to further formation damage. Core flooding experiments demonstrated that reversing flow could increase permeability again by flushing fines out (Pronk et al. 2017). However, fines migration may not in all cases cause a significant impairment in the recovery of oil or gas. Cleverly engineered, the effects of fines migration could be used in order to control water production (Zeinijahromi et al. 2011, 2015).

The main sources of moveable fine particles in natural reservoirs are usually kaolinite and illite clays (Lagasca and Kovscek 2014; Arab et al. 2014). The kaolinite particles in contrast to illite are flat plates stacked in form of booklets (Wilson and Pittman 1977).

This study investigates factors contributing to fines migration in a carbonate formation containing migratory clay minerals. The carbonate reservoir has a high $\mathrm{CO}_{2}$ content. Thus, the effect of $\mathrm{CO}_{2}$-saturated brine and high $\mathrm{CO}_{2}$ dry hydrocarbon gas flow during production was important.

In this study the fines migration potential of a high $\mathrm{CO}_{2}$ content gas field (70 $\mathrm{Mol} \% \mathrm{CO}_{2}$ ), scheduled for development offshore Malaysia Sarawak, is being investigated in detail. This high $\mathrm{CO}_{2}$ content gas field has been identified as a model site to investigate CCS in Malaysia. In particular novel techniques to monitor $\mathrm{CO}_{2}$ in the subsurface, novel stimulation methods as well fines migration are being investigated in detail (Sazali et al. 2018a; Sazali et al. 2018b). Furthermore, scaling and dissolution, geomechanical effects from gas production as well $\mathrm{CO}_{2}$ injection are studied (Sazali et al. 2019).

The carbonate reservoir is located in a platform reef environment (Middle-Late Miocene), located $250 \mathrm{~km}$ northwest of Bintulu under water depths of $80 \mathrm{~m}$. The reservoir is a carbonate structure with dimensions at the fluid contact of approximately $11 \mathrm{~km}$ by $8 \mathrm{~km}$, from north to south, with the hydrocarbon geologically trapped through a four-way dip closure. The maximum hydrocarbon column is $483 \mathrm{~m}$ with

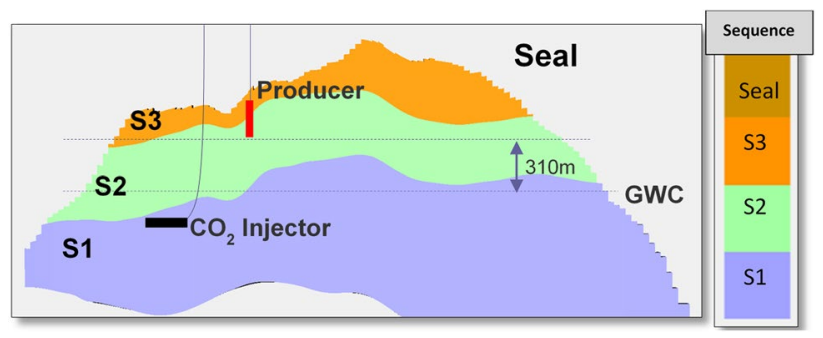

Fig. 1 Reservoir architecture of the proposed gas field 
the interpreted free water level located at $2193 \mathrm{~m}$ true vertical depth subsea (TVDSS).

The carbonate gas reservoir can be subdivided into three formations, subsequently addressed as S1 to S3, with S1 the lowest in the stratigraphy and $\mathrm{S} 3$ the highest (Fig. 1). Preliminary XRD analysis from cores of the production zone revealed an average of $8 \%$ clay content in the samples.

Due to the high clay content of these formations, a study was initiated to investigate formation damage due to fines migration during production from this field. In the following sections, the Materials and methods deployed during the study are described, followed by the results and discussion section and finally the conclusions.

\section{Materials and methods}

In order to determine the impact of fines migration, five core floods were conducted at increasing rate stages with $\mathrm{CO}_{2}$-saturated brine, hydrocarbon gas (70:30 Mol\% $\mathrm{CO}_{2}: \mathrm{N}_{2}$, ) as well as $100 \% \mathrm{CO}_{2}$. Two core floods were performed with hydrocarbon gas and two with $\mathrm{CO}_{2}$-saturated brine. The core floods with $\mathrm{CO}_{2}$-saturated brine were meant to represent water breakthrough at the end of the field life. The actual reservoir contains around $25 \mathrm{Mol} \% \mathrm{CH}_{4}$. Methane was replaced with nitrogen during the core flood in order to adhere to laboratory safety regulations. Mineralogy analysis of S3, S2 and S1 formation rock was conducted using XRD to determine clay types, amount and morphology. Pore-throat size distributions were determined through mercury injection capillary pressure (MICP) test for pore level characterization. Total suspended solids (TSS) were analysed from each incremental rate stage with SEM-EDX analysis (Hitachi S-2600N) performed on the effluents collected. Core flood test was conducted with supercritical $\mathrm{CO}_{2}$.

Core plugs of 1' diameter and 2' length were selected for the study after initial CT scans confirmed the integrity of the core plugs and the absence of fractures. Tracer tests could also aid in selecting core plugs and can help in the field to determine the flow direction of injected fluids (e.g. Gödeke et al. 2006, 2008). The porosity and permeability of the core plugs, together with average pore volume, are presented in Table 1. It can be seen from table one that a range of permeabilities and porosities were investigated. Since no direct core sample was available for the $\mathrm{S} 1$ formation, a core of the $\mathrm{S} 2$ formation with a slightly lower permeability was chosen as analogue for the $\mathrm{S} 1$ formation using additional wireline data as it is known that the permeabilities are lower for the S1 formation. Porosities and permeabilities of core plugs were investigated using Coreeval 700.

For selected samples, MICP experiments were performed at injection pressures of up to $60,000 \mathrm{psi}$ in order to determine pore size distribution as well as permeability distribution curves.

The brine composition used for the study is based on the water analysis from formation water of the reservoir which was simulated to match down-hole conditions (Table 2), since the original fluid sample was collected topside in the absence of reservoir pressure and temperature. Table 2 shows the brine chemistry of the brine used for core floods two and four. The total dissolved solids (TDS) concentration of the formation water which can be characterized as a sodium-chloride type water, is around $7550 \mathrm{mg} / \mathrm{l}$.

The sulphate concentrations were reduced to zero in the brine, to avoid sulphate forming scales (e.g. gypsum) during the experiment. Previous scaling simulation at reservoir pressure and temperature showed that sulphate forming scales can be neglected and that the predominant scales expected are carbonate scales (Sazali et al. 2019).

Table 2 Brine chemistry used for core floods two and four with $\mathrm{CO}_{2}$-saturated brine

\begin{tabular}{ll}
\hline Parameter & $\begin{array}{l}\text { Concen- } \\
\text { tration } \\
(\mathrm{mg} / \mathrm{l})\end{array}$ \\
\hline Sodium & 3848 \\
Chloride & 4651 \\
Calcium & 108 \\
Magnesium & 10 \\
Potassium & 136 \\
Barium & 1 \\
Strontium & 32 \\
Iron & 1.4 \\
Sulphate & 0 \\
Bicarbonate & 475 \\
pH & 5.47 \\
\hline
\end{tabular}

Table 1 Core selection used for core floods

\begin{tabular}{llllll}
\hline Test & Formation & $\begin{array}{l}\text { Av. Kair }(\mathrm{mD} \\
\text { @ 417 psi) }\end{array}$ & Porosity $(\%)$ & $\begin{array}{l}\text { Av. pore vol- } \\
\text { ume }(\mathrm{ml})\end{array}$ & Injection phase \\
\hline 1 & $\mathrm{~S} 3$ & 119.3 & 27.7 & 14.2 & $70: 30 \mathrm{CO}_{2}: \mathrm{N}_{2}$ \\
2 & $\mathrm{~S} 3$ & 117.9 & 31.9 & 18.1 & $\mathrm{CO}_{2}$-saturated brine \\
3 & $\mathrm{~S} 2$ & 146.6 & 27.6 & 17.9 & $70: 30 \mathrm{CO}_{2}: \mathrm{N}_{2}$ \\
4 & $\mathrm{~S} 2$ & 92.1 & 8.8 & 13.5 & $\mathrm{CO}_{2}$-saturated brine \\
5 & S2 (S1 Analogue) & 94.2 & 24.9 & 14.8 & $100 \% \mathrm{CO}_{2}$ \\
\hline
\end{tabular}


In order to mimic reservoir conditions, the core floods were run under the following conditions:

- Overburden pressure: 3172 psi,

- Pore line pressure: 1450 psi,

- Temperature: $136^{\circ} \mathrm{C}$.

The 1722 psi net effective stress was applied using a Gilson pump based on the existing geomechanical model of the reservoir. The temperature, held constant during the experiment at $136{ }^{\circ} \mathrm{C}$, is representative of the average reservoir temperature of the future production zone. Before any incremental rate stages were applied $\mathrm{CO}_{2}$-saturated brine or hydrocarbon gas (70:30 Mol\% $\mathrm{CO}_{2}: \mathrm{N}_{2}$ ) was flooded through the core at baseline rates at ambient as well as at reservoir temperature. These pre-treatment stages were applied to achieve $100 \%$ saturation of the core with either brine or gas prior to any incremental rate stages.

Total suspended solids (TSS) as effluents were determined from the core floods by weight measurement at each rate increment, before and after the core flood. A stainlesssteel metal filter with a mesh size of $2 \mu \mathrm{m}$ was positioned at the outlet side of the core, prior to the outlet pressure relief valve. The metal filter on which the fines accumulated was washed with reverse-osmosis water prior to its removal from the core flooding rig to remove any brine salts which could affect the weight measurement. The TSS measurements are conducted by weighing a filter pre- and post-stage rate increase. One filter is used per stage. The post-stage rate increase filter samples are flushed with reverse-osmosis (RO) water prior to removal from the rig to remove possible salts, ensuring that only carbonates and silicate fines for example are retained. The difference between the pre- and post-stage weight of the filters is calculated with reference to the amount of fluid flowing through the core to derive the TSS value in $\mathrm{mg} / \mathrm{l}$.

In addition, the filters were also investigated using SEM/ EDX analysis to support the TSS data and to characterize the particle type and morphology. For the investigation of the filters with SEM/EDX, the filters were dried overnight at $60{ }^{\circ} \mathrm{C}$.

It is important to use core flooding rates which are representative of the targeted field production rates. The core floods were conducted at increasing rate stages, with each rate stage representative of a different distance to the wellbore based on gas production rates of $200 \mathrm{MMscf} / \mathrm{d}$.

In order to estimate a representative core flooding rate, it was important to calculate a representative down-hole fluid volume first based on the gas law:

$\mathrm{P} \cdot \mathrm{V}=\mathrm{z} \cdot \mathrm{n} \cdot \mathrm{R} \cdot \mathrm{T}$

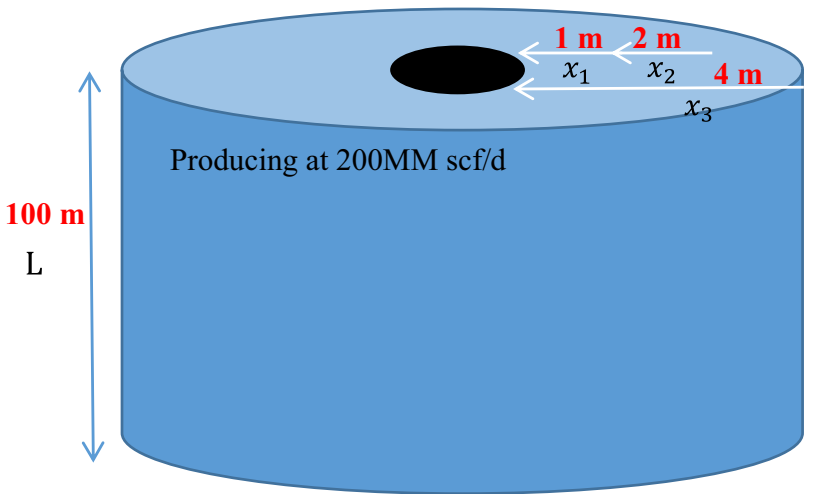

Fig. 2 Sketch of wellbore production interval showing increasing distances away from the wellbore

Table 3 Calculated laboratory flow rates based on distance to the wellbore

\begin{tabular}{lc}
\hline Distance from Wellbore $(\mathrm{m})$ & Flow rate $(\mathrm{ml} / \mathrm{h})$ \\
\hline 0 & 6000 \\
0.5 & 1800 \\
1 & 600 \\
2 & 300 \\
4 & 240 \\
6 & 120 \\
11 & 60 \\
\hline
\end{tabular}

with $\mathrm{P}=$ pressure (psi), $\mathrm{V}=$ volume $\left(\mathrm{ft}^{3}\right), \mathrm{Z}=\mathrm{z}-\mathrm{fac}-$ tor, $\mathrm{n}=$ amount of gas (moles), $\mathrm{R}=$ ideal gas constant, $\mathrm{T}=$ temperature.

The following equation was used:

$V_{B}=\frac{Z_{B} \cdot T_{B} \cdot P_{S} \cdot V_{s}}{Z_{s} \cdot T_{s} \cdot P_{B}}$

with $\mathrm{V}_{\mathrm{B}}=$ volume, bottom-hole, Vs = volume, Surface, $\mathrm{P}_{\mathrm{B}}=$ pressure, bottom-hole, $\mathrm{P}_{\mathrm{S}}=$ pressure, surface, $\mathrm{Ts}=$ temperature, surface, $T_{B}=$ temperature, bottom-hole.

Based on the target injection rate of $200 \mathrm{MM} \mathrm{scf} / \mathrm{d}$ and the above methodology, a representative down-hole fluid volume of $22,844 \mathrm{~m}^{3} / \mathrm{d}$ is calculated. Then, the laboratory flow rate $u_{t}$ can be calculated from the equation:

$u_{t}=\frac{Q}{A}=Q /\left(2 \pi\left(r+x_{i}\right) L\right.$

with $\mathrm{L}=$ production interval (assumed $100 \mathrm{~m}$, based on the planned well design), $Q=$ in this case $22,844 \mathrm{~m}^{3} / \mathrm{d}$, $\mathrm{r}=$ increasing distance from wellbore into the formation ( $\mathrm{m})$. 
Table 4 Clay fraction of selected samples from XRD study

\begin{tabular}{llrllllll}
\hline $\begin{array}{l}\text { Sample depth } \\
(\mathrm{m} \text { MD) }\end{array}$ & Horizon & Total clay $(\%)$ & \multicolumn{6}{l}{ Clay fraction (clay typing, wt\%) } \\
\cline { 5 - 8 } & & & Kaolinite & Chlorite & Illite & $\begin{array}{l}\text { Mixed layer } \\
\text { Silicate }\end{array}$ & Smectite \\
\hline 2050 & S3 & 8.7 & 14.7 & 8.0 & 51.7 & 13.0 & 6.8 \\
2115 & S2 & 8.5 & 14.8 & 7.6 & 53.3 & 11.4 & 7.2 \\
2120 & S2 & 12.2 & 12.6 & 8.7 & 55.8 & 13.6 & 6.4 \\
2125 & S2 & 11.4 & 12.5 & 8.9 & 57.0 & 14.2 & 6.0 \\
1895 & S3 & 23.0 & 17.0 & 8.7 & 48.6 & 12.6 & 6.2 \\
1900 & S3 & 9.9 & 19.3 & 9.7 & 48.8 & 10.1 & 6.0 \\
1905 & S3 & 4.8 & 15.5 & 8.4 & 52.5 & 12.0 & 6.6 \\
\hline
\end{tabular}

The following sketch is useful to visualize the taken approach (Fig. 2).

Thus, first the reservoir velocity is calculated based on the chosen target reservoir production interval. Then the velocity is downscaled to the laboratory rate taking the core radius into account (Table 3). As expected, rates are very high near the sand face area. Thus, in order to investigate the region very close to the wellbore, very high laboratory flow rates would have to be chosen.

The rate of $60 \mathrm{ml} / \mathrm{h}$ represents the baseline saturation rate. The baseline rate was flown until stable differential pressure was reached before any of the incremental rate stages were applied. At each baseline rate permeability was measured in between incremental rate stages and permeability recovery compared to the initial baseline permeability was recorded. After each core flood temperature and pressure were carefully lowered to ambient conditions.

\section{Results and discussion}

The results and discussion presented in this section cover the work from five core floods, XRD analysis, SEM/EDX analysis of expelled solids during the core flood as well as the MICP analysis from selected samples.

The XRD analysis revealed that these formations have an average of $50 \mathrm{wt} \%$ illite, $15 \mathrm{wt} \%$ kalonite, $9 \mathrm{wt} \%$ chlorite and $6 \mathrm{wt} \%$ smectite (Table 4). The reported weight percentages are representative of the total clay fraction. The clay content reaches its highest value further up in the stratigraphy towards the seal (sample depth $1895 \mathrm{~m}$ ). It can be seen that total clay contents greater $10 \%$ can be found in the producing formation (S2). The XRD results also revealed the presence of smectite which can change its swelling behaviour due to changes in salinity (Ahmed et al. 2016).

The mean hydraulic radii from the MICP of the samples varied between 2.7 and $7.1 \mu \mathrm{m}$, with more than $70 \%$ of the permeability associated with pore sizes greater than $10 \mu \mathrm{m}$. The D (10), D (50) and D (90) pore-throat size values from

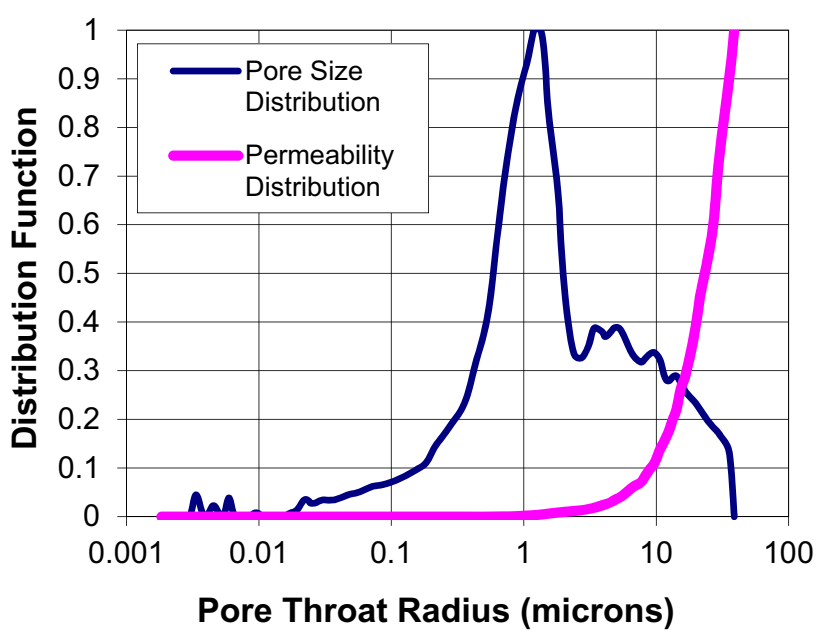

Fig. 3 Pore size and permeability distribution of a bind-stone sample from sample depth $2079.95 \mathrm{~m}$ (S3 formation)

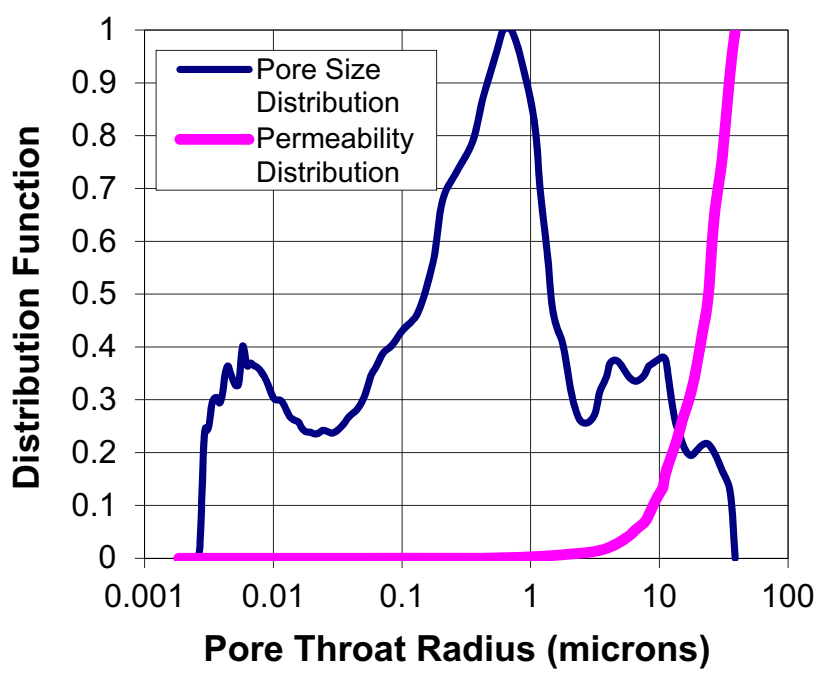

Fig. 4 Pore size and permeability distribution of a float-stone sample from sample depth $2082.05 \mathrm{~m}$ (S3 formation) 


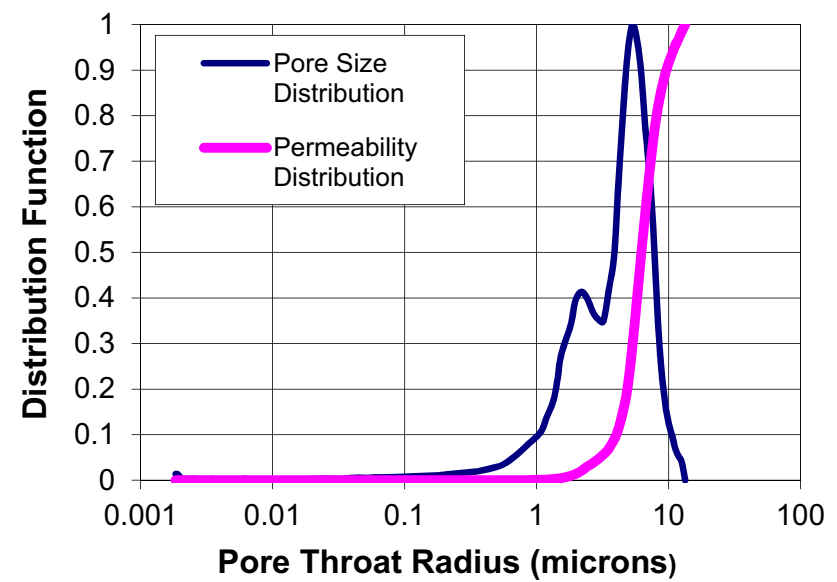

Fig. 5 Pore size and permeability distribution of a frame-stone sample from sample depth of $2086.30 \mathrm{~m}$

the core plugs measured were: $5-15 \mu \mathrm{m} \mathrm{D}(10), 1-9 \mu \mathrm{m} \mathrm{D}$ (50) and $0.02-3 \mu \mathrm{m} \mathrm{D}(90)$. The figures below show pore size and permeability distributions from selected samples (Figs. 3, 4, 5).

All pore size distribution curves are bi- to multi-modal indicating the considerable heterogeneity of the carbonate reservoir. The separation of pore space is important for two-phase flow in general and can result in bypassing of an available cross-sectional area for flow (e.g. Ott et al. 2015a, b).

For the sample in Fig. 4 more than $75 \%$ of the permeability is associated with pore-throat sizes greater $14.2 \mu \mathrm{m}$.

For the sample from Fig. 5 of the S2 formation, the mean hydraulic radius is 2.66 micron. Here, $70 \%$ of the permeability is associated with pore-throat sizes greater $5.3 \mu \mathrm{m}$.

\section{Core flooding results}

In this section the core flooding results (core flood 1 to core flood 5) are presented. The composite chart of baseline and incremental rate stages will be shown for each core flood together with permeabilities measured after each rate stage as well as the analysis of TSS.

\section{Core flood 1}

Before the core was flooded with gas at the prescribed baseline rate, the core was saturated with the hydrocarbon gas $\left(\mathrm{CO}_{2}, \mathrm{~N}_{2}\right)$ until the irreducible water saturation.

Core flood 1 with hydrocarbon gas showed permeability recovery back to $93 \%$ of baseline conditions at flow rates up to $600 \mathrm{ml} / \mathrm{h}$. These results demonstrated that permeability values recovered almost fully compared to baseline levels
Fig. 6 Differential pressure versus time profile recorded during gas saturation at incremental rates and intermediate baseline saturations. Conditions: $\mathrm{CO}_{2}: \mathrm{N}_{2}(70: 30) \mathrm{Po}=3172 \mathrm{psi}$, $\mathrm{Pp}=1450 \mathrm{psi}, T=136{ }^{\circ} \mathrm{C}$

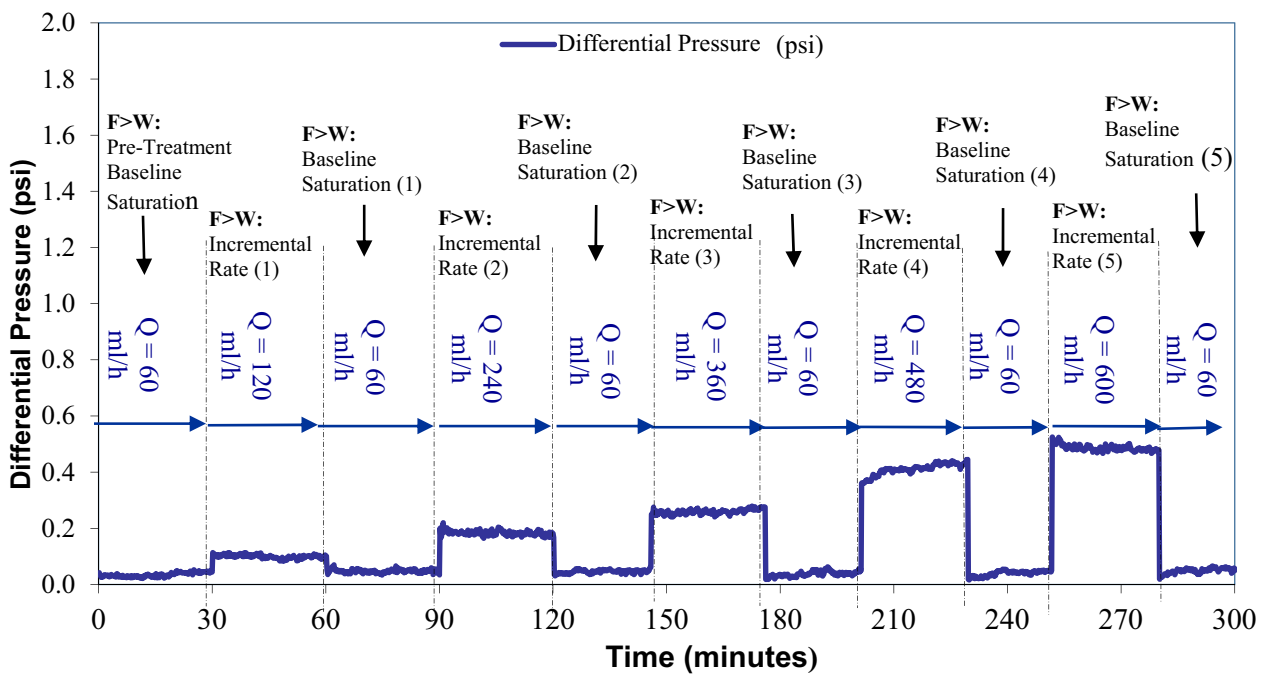

Table 5 Effluent total suspended solids from core flood 1

\begin{tabular}{lllllc}
\hline Stage & Initial weight $(\mathrm{g})$ & Post-weight $(\mathrm{g})$ & Difference $(\mathrm{g})$ & Throughput $(\mathrm{L})$ & TSS $(\mathrm{mg} / \mathrm{L})$ \\
\hline $120 \mathrm{ml} / \mathrm{h}$ & 2.3343 & 2.3347 & 0.0004 & 0.10 & 3.88 \\
$240 \mathrm{ml} / \mathrm{h}$ & 2.3214 & 2.3321 & 0.0107 & 0.22 & 48.06 \\
$360 \mathrm{ml} / \mathrm{h}$ & 2.3168 & 2.318 & 0.0012 & 0.30 & 4.00 \\
$480 \mathrm{ml} / \mathrm{h}$ & 2.3183 & 2.3223 & 0.0040 & 0.29 & 13.89 \\
$600 \mathrm{ml} / \mathrm{h}$ & 2.3121 & 2.314 & 0.0019 & 0.31 & 6.23 \\
\hline
\end{tabular}


Table 6 Permeability measurements for core flood 1, temperature held constant at $136{ }^{\circ} \mathrm{C}$

\begin{tabular}{lrrll}
\hline Stage & $\mathrm{Q}(\mathrm{ml} / \mathrm{h})$ & $\mathrm{K}(\mathrm{mD})$ & Recovery (\%) & Av. dP (psi) \\
\hline Baseline Saturation & 60 & 227.09 & & 0.040 \\
Saturation Rate 1 & 120 & 214.04 & & \\
Baseline Saturation & 60 & 218.43 & 96 & 0.043 \\
Saturation Rate 2 & 240 & 212.87 & & \\
Baseline Saturation & 60 & 226.84 & 100 & 0.041 \\
Saturation Rate 3 & 360 & 233.48 & & \\
Baseline Saturation & 60 & 224.64 & 99 & 0.041 \\
Saturation Rate 4 & 480 & 191.78 & & \\
Baseline Saturation & 60 & 222.58 & 98 & 0.042 \\
Saturation Rate 5 & 600 & 217.90 & & \\
Baseline Saturation & 60 & 211.34 & 93 & 0.052 \\
Baseline Saturation & 60 & 210.43 & 93 & \\
\hline
\end{tabular}

(Fig. 6). Differential pressures during each rate increase reached a stable value, indicating that no progressive formation damage occurred during each rate stage. The cores were flooded in forward mode (formation to wellbore direction).

The effluent total suspended solids data from this test is presented in Table 5.

Overall, the data show very low concentrations of solids being expelled. The greatest release of fines occurs during the $240 \mathrm{ml} / \mathrm{h}$ stage. Overall, the movement of fines recorded by the TSS has had no negative impact on the permeability of the core (Table 6).

The filter analysis using SEM/EDX showed a fines area coverage of the filter of around $1 \%$ in four of the filter samples. At the rate of $240 \mathrm{ml} / \mathrm{h}$ the filter coverage is around $30 \%$. The material on the filters is primarily made up of silicate fines as clay minerals together with rare $\mathrm{CaCO}_{3}$ and salt residue. The clay particles were typically small to medium, ranging from $\sim 5$ to $50 \mu \mathrm{m}$ having angular to sub-angular morphology.

\section{Core flood 2}

Here, the core plug was $100 \%$ saturated with brine (Table 2) which was fully saturated with $\mathrm{CO}_{2}$ prior to core flooding.

The data show that at a laboratory rate of $600 \mathrm{ml} / \mathrm{h}$ representing a distance of $1 \mathrm{~m}$ from the wellbore the permeability recovery value is $80 \%$ (Table 7). After this initial rate increase, no further impairment occurs.

It is also important to note that stable differential pressures are reached during all stages as can be seen from Fig. 7. During the baseline saturation stages, permeabilities tend to slightly increase compared to the previous saturation rate. The reason could be that due to the lower interstitial flow velocities during these stages some fines particles get
Table 7 Permeability measurements for core flood 2, temperature held constant at $136^{\circ} \mathrm{C}$

\begin{tabular}{lrrll}
\hline Stage & $Q(\mathrm{ml} / \mathrm{h})$ & $K(\mathrm{mD})$ & $\begin{array}{l}\text { Permeability } \\
\text { Recovery (\%) }\end{array}$ & Av. dP (psi) \\
\hline $\begin{array}{l}\text { Baseline Satura- } \\
\quad \text { tion 1 }\end{array}$ & 60 & 35.34 & 0.792 \\
$\quad \begin{array}{rrrr}\text { Saturation Rate 1 } \\
\text { Baseline Satura- }\end{array}$ & 120 & 28.61 & & \\
$\quad$ tion 2 & & 29.10 & 82 & 0.974 \\
$\quad$ Saturation Rate 2 & 240 & 27.40 & & \\
Baseline Satura- & 60 & 28.06 & 79 & 1.013 \\
$\quad$ tion 3 & & & & \\
Saturation Rate 3 & 360 & 26.64 & & 1.030 \\
$\begin{array}{l}\text { Baseline Saturation } \\
\text { Saturation Rate 4 }\end{array}$ & 60 & 27.28 & 77 & \\
Baseline Saturation & 60 & 24.92 & & 0.943 \\
Saturation Rate 5 & 600 & 24.97 & 85 & \\
Baseline Saturation & 60 & 28.27 & 80 & 1.010 \\
\hline
\end{tabular}

re-arranged and detach from pore throats and thus slightly increasing the permeability.

Again, low concentrations of solids are expelled during the core flood (Table 8 ). The greatest release of fines occurs during the $120 \mathrm{ml} / \mathrm{h}$ and $240 \mathrm{ml} / \mathrm{h}$ stage with concentrations of 41.5 and $58.5 \mathrm{mg} / \mathrm{l}$, respectively.

It becomes obvious that a high outflow of total suspended solids at a certain flow rate does not correlate with significant permeability drop. Generally, lower flow rates seem to show a greater amount of total suspended solids expelled than during the higher flow rates. It is possible that fines become mobilized already at lower flow rates and then simply start to bridge the pore throats during the higher flow rates and thus reducing the outflow of total suspended solids.

The SEM analysis of the filtrand material showed sparse $\mathrm{CaCO}_{3}$ grains and silicate grains present on all filter samples. Silicate grains were present on all samples except for the $360 \mathrm{ml} / \mathrm{h}$ rate. Silicate and $\mathrm{CaCO}_{3}$ grains could have been released during the dissolution of intergranular cement as a result of the lowering of $\mathrm{pH}$ from the injection of $\mathrm{CO}_{2}$-saturated brine (e.g. Zhang et al. 2020).

\section{Core flood 3}

Core flood 3 performed with $\mathrm{CO}_{2}-\mathrm{N}_{2}$ gas showed very similar results to core flood 1 , with $96 \%$ permeability recovery after four incremental rate stages, with the final rate at $600 \mathrm{ml} / \mathrm{h}$ (Table 9, Fig. 8). Again, only a small number of fines were expelled, with the highest amount measured during the $120 \mathrm{ml} / \mathrm{h}$ stage (Table 10). The SEM-EDX analysis indicated that clay fines as well as iron carbonates were

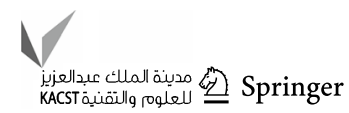


Fig. 7 Differential pressure vs. time profile recorded during brine saturation at incremental rates and intermediate baseline saturations. Conditions: $\mathrm{CO}_{2}$-saturated brine, $\mathrm{Po}=3172$ psi, $\mathrm{Pp}=1450 \mathrm{psi}, \mathrm{T}=136^{\circ} \mathrm{C}$

\begin{tabular}{lllllr}
\hline Stage & Initial Weight $(\mathrm{g})$ & Post-Weight $(\mathrm{g})$ & Difference $(\mathrm{g})$ & Throughput $(\mathrm{L})$ & $\begin{array}{l}\text { TSS } \\
(\mathrm{mg} / \mathrm{L})\end{array}$ \\
\hline $120 \mathrm{ml} / \mathrm{h}$ & 2.3290 & 2.3324 & 0.0034 & 0.08 & 41.46 \\
$240 \mathrm{ml} / \mathrm{h}$ & 2.2995 & 2.3071 & 0.0076 & 0.13 & 58.46 \\
$360 \mathrm{ml} / \mathrm{h}$ & 2.3167 & 2.3172 & 0.0005 & 0.19 & 2.65 \\
$480 \mathrm{ml} / \mathrm{h}$ & 2.3069 & 2.3072 & 0.0003 & 0.34 & 0.88 \\
$600 \mathrm{ml} / \mathrm{h}$ & 2.3127 & 2.3135 & 0.0008 & 0.51 & 1.56 \\
\hline
\end{tabular}

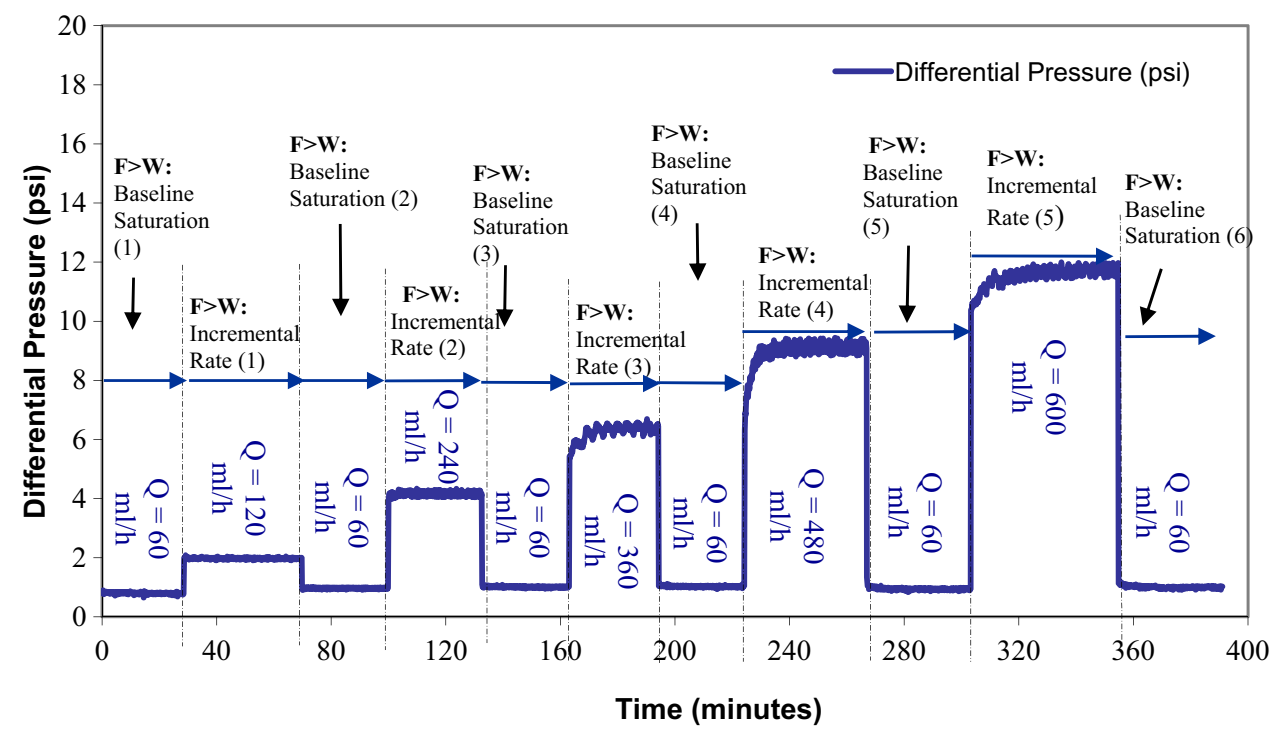

Table 8 TSS measurements for core flood 2
Table 9 Permeability measurements for core flood 3, temperature held constant at $136^{\circ} \mathrm{C}$

\begin{tabular}{lrrll}
\hline Stage & $Q(\mathrm{ml} / \mathrm{h})$ & $K(\mathrm{mD})$ & $\begin{array}{l}\text { Permeability } \\
\text { Recovery (\%) }\end{array}$ & Av. dP (psi) \\
\hline Baseline Saturation & 60 & 160.87 & & 0.078 \\
Saturation Rate 1 & 120 & 213.32 & & \\
Baseline Saturation & 60 & 160.20 & 100 & 0.078 \\
Saturation Rate 2 & 240 & 244.67 & & \\
Baseline Saturation & 60 & 156.63 & 97 & 0.079 \\
Saturation Rate 3 & 360 & 243.04 & & \\
Baseline Saturation & 60 & 156.99 & 98 & 0.079 \\
Saturation Rate 4 & 480 & 258.28 & & 0.081 \\
Baseline Saturation & 60 & 153.04 & 95 & 0.081 \\
Saturation Rate 5 & 600 & 249.73 & & \\
Baseline Saturation & 60 & 153.94 & 96 & \\
\hline
\end{tabular}

expelled. Small quantities of Dolomite grains as well as fossil forms were also identified.

It can be seen that permeabilities almost fully recover to baseline permeabilities. No successive permeability decrease after increasing rate stages can be identified. Stable injectivities were reached for each stage.
Core flood 3 showed the lowest number of solids expelled compared to the other core floods. Since this core showed dolomitic grains, it is possible that less solids were expelled due to a slightly different mineralogy compared to the other core plugs.

\section{Core flood 4}

This core flood was performed with $\mathrm{CO}_{2}$-saturated brine. It showed permeability recovery back to $63 \%$ of baseline conditions at flow rates of $600 \mathrm{ml} / \mathrm{h}$. For this core flood the rates were raised to rates representative of the sand face area (Fig. 9). The results demonstrated that permeability values declined during rates up to $600 \mathrm{ml} / \mathrm{h}$ (Table 11).

At flow rates of $600 \mathrm{ml} / \mathrm{h}$, the permeability dropped to $64 \%$ of the initial permeability which represents a significant permeability reduction. It becomes obvious that the highest amount of formation damage occurs for the flow rate of $600 \mathrm{ml} / \mathrm{h}$. At the next higher rate of $1800 \mathrm{ml} / \mathrm{h}$, the permeability did not decrease further but slightly increased. After the rate $6000 \mathrm{ml} / \mathrm{h}$, it is obvious from the significant permeability increase (343\% compared to the initial permeability) that the high rates led to the permeability increase. First at flow rates of $1800 \mathrm{ml} / \mathrm{h}$ 
Table 10 Effluent total suspended solids for core flood 3

\begin{tabular}{lllllc}
\hline Stage & Initial Weight (g) & Post-Weight (g) & Difference (g) & Throughput (L) & TSS (mg/L) \\
\hline $60 \mathrm{ml} / \mathrm{h}$ & 2.3028 & 2.3047 & 0.0019 & 0.40 & 4.81 \\
$120 \mathrm{ml} / \mathrm{h}$ & 2.3162 & 2.3173 & 0.0011 & 0.10 & 10.82 \\
$240 \mathrm{ml} / \mathrm{h}$ & 2.3142 & 2.315 & 0.0008 & 0.18 & 4.34 \\
$360 \mathrm{ml} / \mathrm{h}$ & 2.3043 & 2.3046 & 0.0003 & 0.16 & 1.85 \\
$480 \mathrm{ml} / \mathrm{h}$ & 2.3485 & 2.3493 & 0.0008 & 0.30 & 2.70 \\
\hline
\end{tabular}

Fig. 8 Differential pressure versus time profile recorded during gas saturation at incremental rates and intermediate baseline saturations. Conditions: $\mathrm{CO}_{2}: \mathrm{N}_{2}(70: 30) \mathrm{Po}=3172 \mathrm{psi}$, $\mathrm{Pp}=1450 \mathrm{psi}, T=136^{\circ} \mathrm{C}$
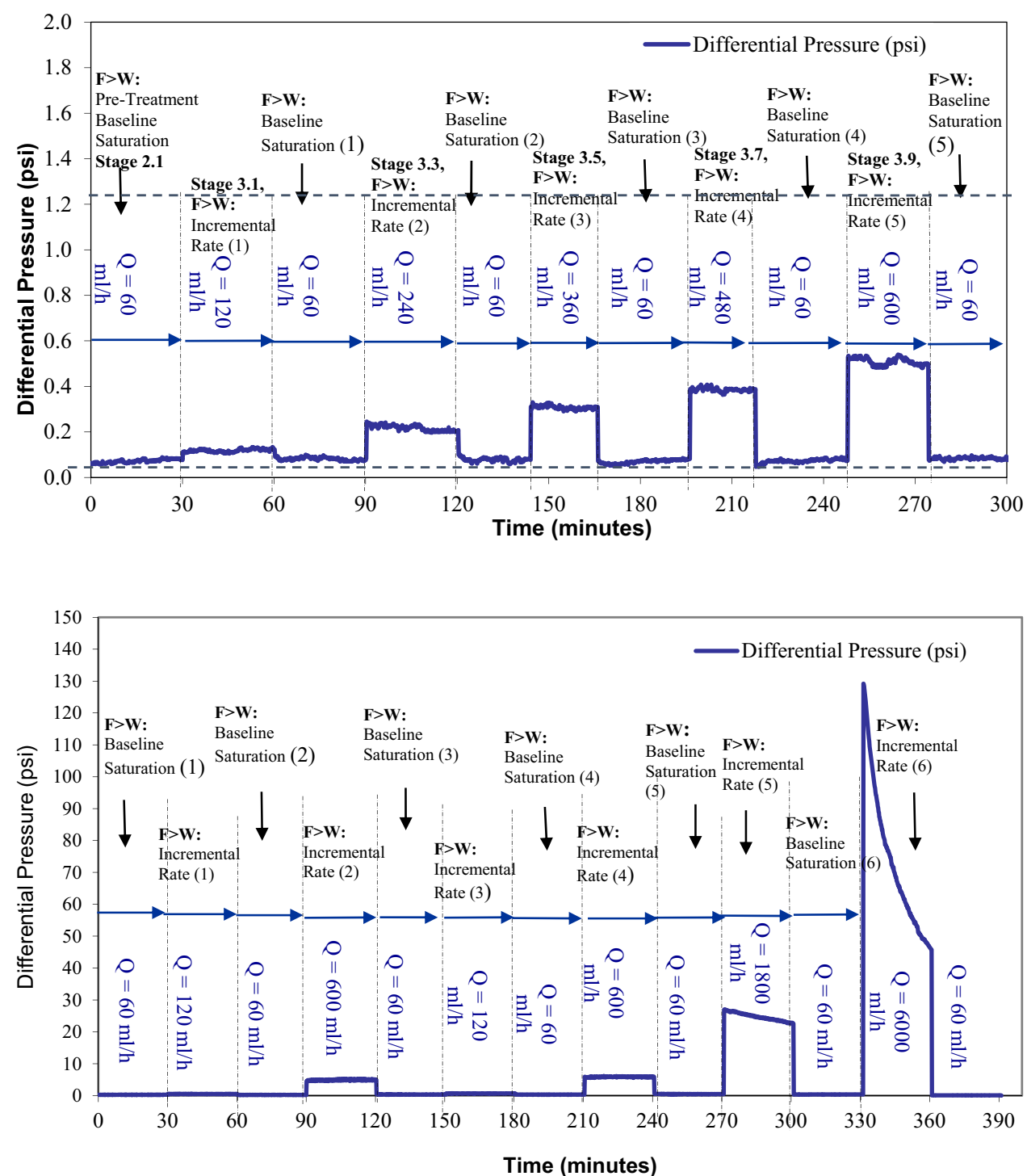

Time (minutes)
Fig. 9 Differential pressure versus time profile recorded during brine saturation at incremental rates and intermediate baseline saturations. Conditions: $\mathrm{CO}_{2}$-saturated brine, $\mathrm{Po}=3172$ psi, $\mathrm{Pp}=1450 \mathrm{psi}, T=136^{\circ} \mathrm{C}$ permeabilities started to increase again to $75 \%$ of baseline levels. The high flow velocities seemed to reverse the formation damage possibly creating preferential flow-paths; however, the core face got slightly eroded and no stable differential pressure was reached at that stage (Fig. 9, Supplementary Figure). An increase in flow rate did not correspond to an increased level of TSS released. It is therefore possible that most of the fines damage was in the first section of the core from the injector and thus the fines damage may not be homogenously distributed throughout the core. The TSS concentrations showed a decreasing trend with time, generally indicating particle capture (Table 12). The effluent filter analysis shows again low levels of expelled solids similar to previous tests. Coinciding with the permeability and injectivity data from the previous table which indicated fines movement at rates above $120 \mathrm{ml} / \mathrm{h}$, increased levels of fines are released at rates above $120 \mathrm{ml} / \mathrm{h}$. The difference in weight pre- and 
Table 11 Permeability and baseline differential pressures for core flood 4, temperature held constant at $136^{\circ} \mathrm{C}$

\begin{tabular}{lrrll}
\hline Stage & $Q(\mathrm{ml} / \mathrm{h})$ & $K(\mathrm{mD})$ & $\begin{array}{l}\text { Permeability } \\
\text { Recovery (\%) }\end{array}$ & Av. dP (psi) \\
\hline Baseline Saturation & 60 & 94.95 & & 0.26 \\
Saturation Rate 1 & 120 & 104.83 & & 0.21 \\
Baseline Saturation & 60 & 121.35 & 128 & \\
Saturation Rate 2 & 600 & 52.29 & & 0.34 \\
Baseline Saturation & 60 & 75.79 & 80 & \\
Saturation Rate 3 & 120 & 76.55 & & 0.31 \\
Baseline Saturation & 60 & 81.56 & 86 & 0.42 \\
Saturation Rate 4 & 600 & 44.20 & & \\
Baseline Saturation & 60 & 60.50 & 64 & 0.36 \\
Saturation Rate 5 & 1800 & 34.08 & & 0.08 \\
Baseline Saturation & 60 & 70.93 & 75 & \\
Saturation Rate 6 & 6000 & 55.53 & & \\
Baseline Saturation & 60 & 325.34 & 343 & \\
\hline
\end{tabular}

post-stage for the experiment are greatest during these high rates showing that the weight of the core plug is being reduced which confirms the erosion of the core face.

Again, filtrand samples were analysed with SEM for each flow rate. The two highest incremental rates of 1800 and $6000 \mathrm{ml} / \mathrm{h}$ showed the highest levels of fines coverage of 30 and $10 \%$ on the filter material, respectively. The filtrate material is predominantly silicate and lesser carbonate.

In addition, digital images pre- and post-test of the core faces were taken. Inlet and outlet faces show larger openings also aligned with fossils and vugs. Fine material appears to have been physically washed out from the core at the higher flow rates creating flow-paths. Visible are also pin holes on the core faces (Supplementary Figure).

\section{Core flood 5}

The injection of $\mathrm{CO}_{2}$ may cause salt precipitation due to formation dry-out around the injection zone. Salt precipitation due to $\mathrm{CO}_{2}$ injection has been previously investigated (Ott et al. 2015a; Andre et al. 2014; Muller et al. 2009; Pruess
2009). The investigations showed that salt precipitation (e.g. Halite) due to $\mathrm{CO}_{2}$ injection in subsurface formations can lead to permeability and porosity reduction.

This test was performed as a combined $\mathrm{CO}_{2}$ injection salt dropout test meaning supercritical $\mathrm{CO}_{2}$ is injected first to the point of irreducible water saturation of the core plug; then subsequently $\mathrm{CO}_{2}$ rates were increased (Fig. 9). Before the rates were rates more than $100 \mathrm{PV}$ of $\mathrm{CO}_{2}$ were injected. The differential pressure plot shows stable differential pressures during the $\mathrm{CO}_{2}$ injection phase, indicating no sign of formation damage due to mineral precipitation. The core was saturated with brine before injection of $\mathrm{CO}_{2}$.

The brine permeability for the baseline rate of $60 \mathrm{ml} / \mathrm{h}$ was measured to be $57 \mathrm{mD}$. After a rate increase to $120 \mathrm{ml} / \mathrm{h}$, the permeability recovers fully to the baseline permeability suggesting no sign of formation damage. At the second rate increase of $240 \mathrm{ml} / \mathrm{h}$, the permeability reduced to $79 \%$ of the initial and at a further increased rate of $600 \mathrm{ml} / \mathrm{h}$ the rate reduced further to $74 \%$ of the initial permeability. Thus, for this experiment a critical rate for fines movement of $240 \mathrm{ml} / \mathrm{h}$ can be formulated.

A brine saturation post-treatment showed a full permeability recovery (118\%) to baseline permeability (Table 13), demonstrating that no irreversible formation damage has

Table 13 Permeability and baseline differential pressure for core flood 5, temperature held constant at $136{ }^{\circ} \mathrm{C}$

\begin{tabular}{lrrll}
\hline Stage & $Q(\mathrm{ml} / \mathrm{h})$ & $K(\mathrm{mD})$ & $\begin{array}{l}\text { Permeability } \\
\text { Recovery (\%) }\end{array}$ & Av. dP (psi) \\
\hline $\begin{array}{l}\text { Baseline Brine } \\
\quad \text { Saturation }\end{array}$ & 60 & 67.45 & & 0.49 \\
$\quad$ Main Injection & 60 & 56.73 & & 0.22 \\
Saturation Rate 1 & 120 & 41.76 & & \\
Baseline Saturation & 60 & 56.84 & 100 & 0.23 \\
Saturation Rate 2 & 240 & 31.34 & & \\
Baseline Saturation & 60 & 44.81 & 79 & 0.29 \\
Saturation Rate 3 & 600 & 28.38 & & \\
Baseline Saturation & 60 & 41.82 & 74 & 0.31 \\
Baseline Brine & 60 & 76.58 & 118 & 0.43 \\
$\quad$ Saturation & & & & \\
\hline
\end{tabular}

Table 12 Effluent total suspended solids for core flood 4

\begin{tabular}{lllllr}
\hline $\begin{array}{l}\text { Rate Stage } \\
(\mathrm{ml} / \mathrm{h})\end{array}$ & Initial Weight $(\mathrm{g})$ & $\begin{array}{l}\text { Post-Weight } \\
(\mathrm{g})\end{array}$ & Difference $(\mathrm{g})$ & $\begin{array}{l}\text { Throughput } \\
(\mathrm{L})\end{array}$ & $\begin{array}{l}\text { TSS } \\
(\mathrm{mg} / \mathrm{l})\end{array}$ \\
\hline 60 & 2.2904 & 2.2907 & 0.0003 & 0.05 & 6.41 \\
120 & 2.2753 & 2.2776 & 0.0023 & 0.06 & 37.92 \\
600 & 2.3211 & 2.3222 & 0.0011 & 0.07 & 15.71 \\
120 & 2.2739 & 2.2746 & 0.0007 & 0.07 & 10.00 \\
600 & 2.2977 & 2.2986 & 0.0009 & 0.30 & 2.97 \\
1800 & 2.2778 & 2.2801 & 0.0023 & 0.38 & 5.99 \\
6000 & 2.2784 & 2.28 & 0.0016 & 2.19 & 0.73 \\
\hline
\end{tabular}


occurred. From Table 13 and the comparative chart (Fig. 10) it becomes obvious that no spikes in differential pressures are observed.

The effluent analysis displays similar concentrations of total dissolved solids being expelled compared to previous filter analysis. The greatest release of fines occurred during the initial main $\mathrm{CO}_{2}$ injection (Table 14), which is consistent with core floods one and three. No significant contribution from precipitated salts has been discovered from the effluent analysis with the dominant expelled solid identified as carbonate.

The following table summarized the results of all five core floods (Table 15).

The comparison table shows that final permeability recovery for the core floods with dry $\mathrm{CO}_{2}-\mathrm{N}_{2}$ gas was the highest showing no significant formation damage occurred. The highest permeability reduction was observed during core
Fig. 10 Differential pressure versus time profile recorded during $\mathrm{CO}_{2}$-saturated brine saturations at incremental rates and intermediate baseline saturations for core flood 5 . Conditions: $\mathrm{Po}=3172 \mathrm{psi}, \mathrm{Pp}=1450$ psi, $T=136{ }^{\circ} \mathrm{C}$

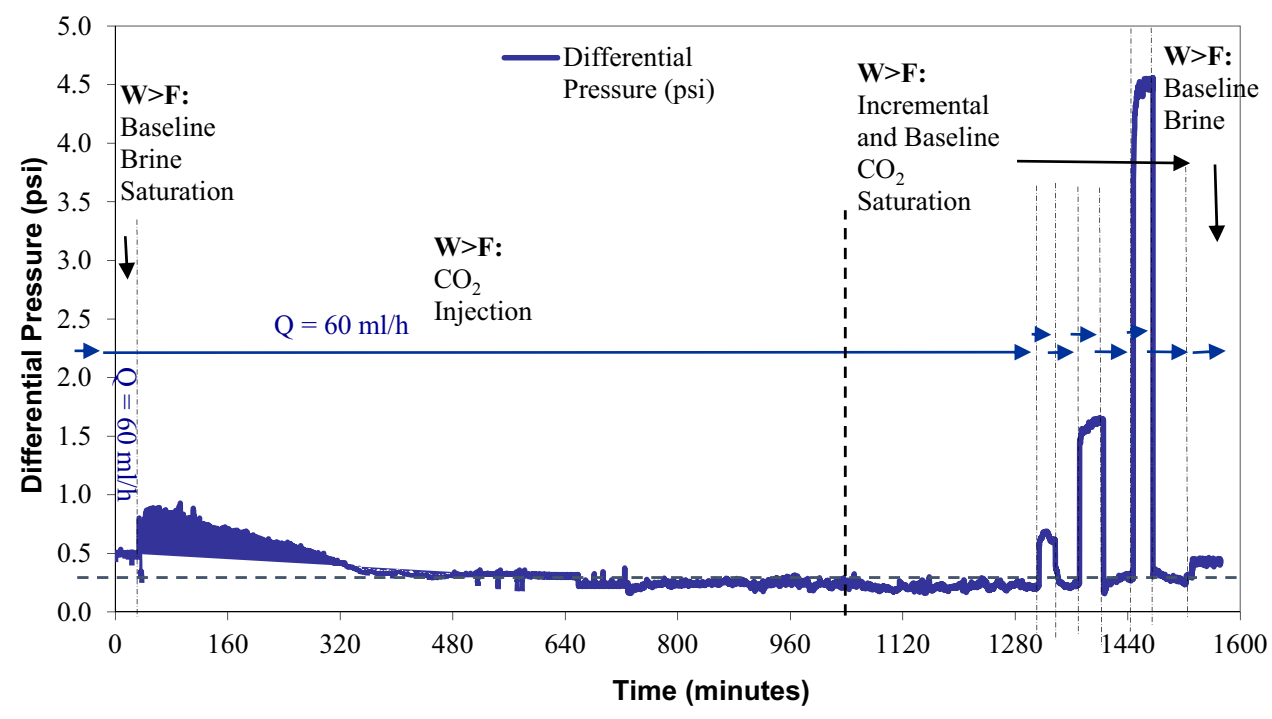

Table 14 Effluent total suspended solids for core flood 5

\begin{tabular}{|c|c|c|c|c|c|}
\hline Stage & Initial Weight (g) & Post-Weight (g) & Difference (g) & Throughput (L) & TSS (mg/L) \\
\hline Main $\mathrm{CO}_{2}$ Injection (1) & 2.2848 & 2.3047 & 0.0199 & 0.47 & 42.77 \\
\hline Main $\mathrm{CO}_{2}$ Injection (2) & 2.2991 & 2.3058 & 0.0067 & 0.42 & 16.00 \\
\hline Main $\mathrm{CO}_{2}$ Injection (3) & 2.2779 & 2.2798 & 0.0019 & 0.41 & 4.59 \\
\hline 120 ml/h (gas) & 2.3186 & 2.3195 & 0.0009 & 0.06 & 14.36 \\
\hline 240 ml/h (gas) & 2.2753 & 2.2770 & 0.0017 & 0.15 & 11.09 \\
\hline 600 ml/h (gas) & 2.2847 & 2.2877 & 0.0030 & 0.30 & 10.06 \\
\hline
\end{tabular}

Table 15 Result comparison of fines mobilization core floods

\begin{tabular}{|c|c|c|c|c|c|}
\hline Test & 1 & 2 & 3 & 4 & 5 \\
\hline Injection Phase & $70: 30 \mathrm{CO}_{2}: \mathrm{N}_{2}$ & $\mathrm{CO}_{2}$-Saturated Brine & $70: 30 \mathrm{CO}_{2}: \mathrm{N}_{2}$ & $\mathrm{CO}_{2}$-Saturated Brine & $100 \% \mathrm{CO}_{2}$ \\
\hline Formation & S3 & S3 & $\mathrm{S} 2$ & $\mathrm{~S} 2$ & S1 (analogue) \\
\hline Flow Rates & $60-600 \mathrm{ml} / \mathrm{h}$ & $60-600 \mathrm{ml} / \mathrm{h}$ & $60-600 \mathrm{ml} / \mathrm{h}$ & $60-6000 \mathrm{ml} / \mathrm{h}$ & $60-600 \mathrm{ml} / \mathrm{h}$ \\
\hline Injectivity & Stable & Stable & Stable & Stable & Stable \\
\hline Final Recovery & $93 \%$ & $80 \%$ & $96 \%$ & $\begin{array}{l}64 \% \text { (to } 600 \mathrm{ml} / \mathrm{h} \text { ) } \\
>300 \% \text { (to } 6000 \mathrm{ml} / \mathrm{h} \text { ) }\end{array}$ & $74 \%$ \\
\hline Critical Damage Rate & $>600 \mathrm{ml} / \mathrm{h}$ & $120 \mathrm{ml} / \mathrm{h}$ & $>600 \mathrm{ml} / \mathrm{h}$ & $600 \mathrm{ml} / \mathrm{h}$ & $240 \mathrm{ml} / \mathrm{h}$ \\
\hline TSS Peak Conc. & $48 \mathrm{mg} / \mathrm{l}$ & $58 \mathrm{mg} / \mathrm{l}$ & $11 \mathrm{mg} / \mathrm{l}$ & $38 \mathrm{mg} / \mathrm{l}$ & $43 \mathrm{mg} / \mathrm{l}$ \\
\hline Dominant Filtrand & Silicate & Silicate/Carbonate & Silicate & Silicate/Carbonate & Carbonate \\
\hline
\end{tabular}


flood 4 for the core with the lowest porosity $(8.8 \%)$. This formation damage was then reversed at very high flow rate; however, the core face was eroded during these high rates. Overall the total amount of suspended solids was low, the expelled amount of expelled carbonate could indicate that due the injection of $\mathrm{CO}_{2}$-saturated brine carbonate got dissolved which could also lead to the dislodging of fines (e.g. Othman et al. 2018).

\section{Conclusions}

This study is one of the few studies which investigated fines migration for a carbonate reservoir scheduled for gas production and re-injection of produced $\mathrm{CO}_{2}$. The results demonstrate that fines migration in carbonates can be an issue. Several important conclusions can be drawn from the work:

- The greatest amount of formation damage was observed for the core with the porosity of $10 \%$, showing the greater risk of formation damage due to fines migration at lower porosities;

- Overall a high potential for fines migration in this type of carbonate system exists for $\mathrm{CO}_{2}$-saturated brine flow. The core floods with $\mathrm{CO}_{2}-\mathrm{N}_{2}$ gas showed no sign of formation damage at increasing rate stages;

- Thus, formation damage due to fines migration is more prominent when fines can move with the brine (water wet phase), which is in agreement with findings in the literature (e.g. Muecke 1979);

- It is therefore expected that fines migration would only start to affect production at a later stage in the field life, once water production from the reservoir increases;

- Increasing rate stages did not necessarily lead to increasing formation damage;

- The resulting formation damage observed from core flood 4 was not irreversible, because higher rates leading to core face erosion could significantly improve the permeability of the core plug. An explanation for this could be that the formation damage e.g. due to blockage of pore throats is not evenly distributed throughout the core plug but more prominent at the core inlet.

- The combined salt dropout and fines mobilization core flood 5 showed a higher degree of formation damage due to fines mobilization with $74 \%$ permeability recovery compared to baseline permeability compared to core floods 1 and 3. However, the formation damage due to fines mobilization was reversible.

Overall a high potential for fines migration in this type of carbonate system exist for $\mathrm{CO}_{2}$-saturated brine flow. The critical rate for fines movement determined from the core floods was $120 \mathrm{ml} / \mathrm{h}$. There is a less significant formation damage potential for dry $\mathrm{CO}_{2}$ flow. $100 \% \mathrm{CO}_{2}$ injection may cause permeability impairment at rates exceeding $120 \mathrm{ml} / \mathrm{h}$, representative of a field rate of $6 \mathrm{~m}$ from the wellbore at production rates of $200 \mathrm{MM} \mathrm{scf/d}$.

Acknowledgements The authors thank PETRONAS for allowing the publication of this study. The authors thank two anonymous reviewers for their comments which helped to improve the manuscript.

Open Access This article is licensed under a Creative Commons Attribution 4.0 International License, which permits use, sharing, adaptation, distribution and reproduction in any medium or format, as long as you give appropriate credit to the original author(s) and the source, provide a link to the Creative Commons licence, and indicate if changes were made. The images or other third party material in this article are included in the article's Creative Commons licence, unless indicated otherwise in a credit line to the material. If material is not included in the article's Creative Commons licence and your intended use is not permitted by statutory regulation or exceeds the permitted use, you will need to obtain permission directly from the copyright holder. To view a copy of this licence, visit http://creativecommons.org/licenses/by/4.0/.

\section{References}

Ahmed AA, Saaid IM, Akhir NAM, Rashedi M (2016) Influence of various cation valence, salinity, $\mathrm{pH}$ and temperature on bentonite swelling behaviour. AIP Conf Proc. https://doi. org/10.1063/1.4965087

Ali NEC, Al-Sammaraie M, Gödeke S, Benquet J-C, Aubry E, Julien P, Gharbi O (2015) An experimental study of water production mitigation and improved acid diversion during acid injection in heterogeneous carbonates. In: International petroleum technology conference, 6-9 December, Doha, Qatar. https://doi. org/10.2523/iptc-18382

André L, Peysson Y, Azaroual M (2014) Well injectivity during $\mathrm{CO}_{2}$ storage operations in deep saline aquifers: Part 2: numerical simulations of drying, salt deposit mechanisms and role of capillary forces. Int J Greenh Gas Control 22:301-312. https://doi. org/10.1016/j.ijggc.2013.10.030

Arab D, Pourafshary P, Ayatollahi Sh, Habibi A (2014) Remediation of colloid facilitated contaminant transport in saturated porous media treated with nanoparticles. Int J Environ Sci Technol 11(1):207-216

Bedrikovetsky P, Siqueira FD, Furtado CA, Souza ALS (2011) Modified particle detachment model for colloidal transport in porous media. Transp Porous Media 86(2):353-383. https://doi. org/10.1007/s11242-010-9626-4

Bennion B (1999) Formation damage-the impairment of the invisible, by the inevitable and uncontrollable, resulting in an indeterminate reduction of the unquantifiable. JCPT, vol 38, no. 2, PETSCO-99-02-DA. https://doi.org/10.2118/99-02-DA

Bennion BD, Thomas BF, Ma T (2000) Formation damage processes reducing productivity of low permeability gas reservoirs, SPE 60325. In: Proceeding of the SPE rocky mountains regional/ low permeability reservoir symposium and exhibition, Denver, Colorado, USA, 12-15 March

Civan F (2014) Reservoir formation damage, 3rd edn. Gulf Professional Publishing, Burlington

Economides MJ, Hill AD, Ehlig-Economides C, Zhu D (2013) Petroleum production systems, 2nd edn. Prentice Hal, New york 
Frenier WW, Ziauddin M (2014) Chemistry for enhancing the production of oil and gas. Society of Petroleum Engineers. ISBN:978-1-61399-317-0

Gharbi O, Goedeke S, Al-Sammaraie M, Al-Shahwani S, Cheneviere P, Al-Mohannadi N, Julien P (2014) Core flood analysis of acid stimulation in carbonates: towards effective diversion and water mitigation, SPE-, IPTC 2014: unlocking energy through innovation. Technol Capabil 4(2014):3270-3274. https://doi. org/10.2523/IPTC-17608-MS

Gödeke S, Richnow HH, Weiß H, Fischer A, Borsdorf H, Schirmer M (2006) Multi tracer test for the implementation of enhanced in-situ bioremediation at a BTEX-contaminated megasite. J Contam Hydrol 87(3-4):211-236. https://doi.org/10.1016/j.jconh yd.2006.05.008

Gödeke S, Geistlinger H, Fischer A, Richnow H-H, Schirmer M (2008) Simulation of a reactive tracer experiment using stochastic hydraulic conductivity fields. Environ Geol 55(6):12551261. https://doi.org/10.1007/s00254-007-1073-3

Goedeke S, Hossain MdM (2012) Simulation of a shale gas field development: an example from Western Australia. In: Society of Petroleum Engineers-SPE Middle East Unconventional Gas Conference and Exhibition 2012. UGAS-Unlocking Unconventional Gas: New Energy in the Middle East, pp 315-324. https:// doi.org/10.2118/152110-MS

Kashim MZ, Giwelli A, Clennell B, Esteban L, Noble R, Vialle S, Ghasemiziarani M, Saedi A, Md Shah SS, Ibrahim JM (2019) Determining critical flowrate in high $\mathrm{CO}_{2}$ content carbonate field, Sarawak Basin. Offshore East Malaysia. https://doi. org/10.2523/iptc-19422-ms

Lagasca JRP, Kovscek AR (2014) Fines migration and compaction in diatomaceous rocks. J Pet Sci Eng 122:108-118

Miranda, R.M., Underdown, D.R., (1993): Laboratory measurement of critical rate: a novel approach for quantifying fines migration problems, SPE 25432. Proceeding of the SPE Production Operations Symposium. Oklahoma City, Oklahoma, USA, 21-23 March

Muecke TW (1979) Formation fines and factors controlling their movement in porous media. JPT 31(2):144-150. https://doi. org/10.2118/7007-pa

Muller N, Qi R, Mackie E, Pruess K, Blunt MJ (2009) $\mathrm{CO}_{2}$ injection impairment due to halite precipitation. Energy Procedia 1:35073514. https://doi.org/10.1016/j.egypro.2009.02.143

Oliveira MA, Vaz SL, Siqueira FD, Yang Y, You Z (2014) Slow migration of mobilised fines during flow in reservoir rocks: Laboratory study. J Petrol Sci Eng 122(2014):534-541

Othman F, Yu M, Kamali F, Hussain F (2018) Fines migration during supercritical $\mathrm{CO}_{2}$ injection in sandstone. J Nat Gas Sci Eng 56:344-357

Ott H, Pentland CH, Oedai S (2015a) CO2-brine displacement in heterogeneous carbonates. Int J Greenh Gas Control 33:135-144. https://doi.org/10.1016/j.ijggc.2014.12.004

Ott H, Roels SM, de Kloe K (2015b) Salt precipitation due to supercritical gas injection: I. Capillary-driven flow in unimodal sandstone. Int J Greenh Gas Control 43:247-255. https://doi.org/10.1016/j. ijggc.2015.01.005

Paveley C (2002) Blake seawater injection: well performance optimisation, SPE 73783. In: Proceeding of the SPE international symposium and exhibition on formation damage control, Lafayette, Louisiana, USA, 20-21 February

Pearce JK, Dawson GKW, Golab A, Knuefing L, Sommacal S, Rudolph V, Golding SD (2019) A combined geochemical and MCT study on the $\mathrm{CO}_{2}$ reactivity of Surat Basin reservoir and cap-rock cores: porosity changes, mineral dissolution and fines migration. Int $\mathbf{J}$ Greenh Gas Control 80:10-24. https://doi.org/10.1016/j.ijggc .2018.11.010

Pronk R, Russell T, Pham D, Tangparitkul S, Badalyan A, Behr A, Genolet L, Kowollik P, Zeinijahromi A, Bedrikovetsky P (2017)
Non-Monotonic permeability variation during fines migration: laboratory study, Asia Pacific Oil and Gas Conference and Exhibition, 17-19 October, Jakarta, Indonesia, 186231-MS SPE conference paper

Pruess K (2009) Formation dry-out from $\mathrm{CO}_{2}$ injection into saline aquifers: 2. Analytical model for salt precipitation. Water Resour Res 45:1-6. https://doi.org/10.1029/2008WR007102

Russell T, Chequer L, Borazjani S, You Z, Zeinijahromi A, Bedrikovetsky P (2018) Formation damage by fines migration. Form Dam During Improv Oil Recov. https://doi.org/10.1016/b978-012-813782-6.00003-8

Sazali Y, Gödeke S, Sazali WL, Ibrahim JM, Graham GM, Kidd SL, Ohen HA (2018a) Fines migration during $\mathrm{CO}_{2}$ saturated brine flow in carbonate reservoirs with some migratory clay minerals: the Malaysian formations. In: Proceedings-SPE international symposium on formation damage control. https://doi. org/10.2118/189569-MS

Sazali Y, Misra S, Sazali WL, Ibrahim JM, Graham GM, Kidd SL, Ohen HA, Gödeke S (2018b) Evaluation of the effectiveness of matrix stimulation recipes for high $\mathrm{CO}_{2}$ carbonate reservoirs for bypassing formation damage. In: Proceedings-SPE international symposium on formation damage control. https://doi. org/10.2118/189567-MS

Sazali YA, Sazali WML, Ibrahim JM, Dindi M, Graham G, Gödeke S (2019) Investigation of high temperature, high pressure, scaling and dissolution effects for carbon capture and storage at a high $\mathrm{CO}_{2}$ content carbonate gas field offshore Malaysia. J Pet Sci Eng 174:599-606. https://doi.org/10.1016/j.petrol.2018.11.060

Schembre JM, Kovscek AR (2005) Mechanism of formation damage at elevated temperature. J Energy Resour Technol 127:171-180. https://doi.org/10.1115/1.1924398

Sokama-Neuyam YA, Ginting PUR, Timilsina B, Ursin JR (2017) The impact of fines mobilization on $\mathrm{CO}_{2}$ injectivity: an experimental study. Int J Greenh Gas Control 65:195-202. https://doi. org/10.1016/j.ijggc.2017.08.019

Watson RB (2001) Optimising gravel pack performance in a high rate gas development, SPE 68969. In: Proceeding of the SPE European formation damage conference. The Hague, Netherlands, 21-22 May

Wilson MD, Pittman ED (1977) Authigenic clays in sandstones; recognition and influence on reservoir properties and paleoenvironmental analysis. J Sedim Res 47:3-31

Xie Q, Saeedi A, Delle Piane C, Esteban L, Brady PV (2017) Fines migration during $\mathrm{CO}_{2}$ injection: experimental results interpreted using surface forces. Int J Greenh Gas Control 65:32-39. https:// doi.org/10.1016/j.ijggc.2017.08.011

Zeinijahromi A, Lemon P, Bedrikovetsky P (2011) Effects of induced fines migration on water cut during waterflooding. J Petrol Sci Eng 78(2011):609-617

Zeinijahromi A, Al-Jassasi H, Begg S, Bedrikovetsky P (2015) Improving sweep efficiency of edge-water drive reservoirs using induced formation damage. J Petrol Sci Eng 130:123-129. https://doi. org/10.1016/j.petrol.2015.04.008

Zhang X, Ge J, Kamali F, Othman F, Wang Y, Le-Hussain F (2020) Wettability of sandstone rocks and their mineral components during $\mathrm{CO}_{2}$ injection in aquifers: implications for fines migration. J Nat Gas Sci Eng 73:103050. https://doi.org/10.1016/j.jngse .2019 .103050

Publisher's Note Springer Nature remains neutral with regard to jurisdictional claims in published maps and institutional affiliations. 